\title{
Analisis Efektivitas Iklan Televisi dan Faktor yang Mempengaruhi Keputusan Pembelian Es Krim Wall's Magnum Berdasarkan Karakteristik Gender (Studi Kasus Mahasiswa Program Strata-1 IPB)
}

\author{
Indri Astriyani \\ Alumni Departemen Manajemen, Fakultas Ekonomi dan Manajemen \\ Institut Pertanian Bogor \\ Muhammad Syamsun \\ Departemen Manajemen, Fakultas Ekonomi dan Manajemen \\ Institut Pertanian Bogor \\ R. Dikky Indrawan \\ Departemen Manajemen, Fakultas Ekonomi dan Manajemen \\ Institut Pertanian Bogor \\ Email: rdikky@yahoo.com
}

\begin{abstract}
Magnum Manufacturers need to consider the differences between women and men in decision-making purchase of Magnum ice cream. On this basis, the purpose of this study was to (1) Magnum television advertising effectiveness analysis in communicating the advertising message by gender in student-Tier 1, Bogor Agricultural University, (2) analyze the factors that influence the purchase of real students by gender in the purchase Wall's Magnum ice cream by student stratum-1 Institut Pertanian Bogor. Analysis of the data used are Consumer Decision Model (CDM) and Canonical Correlation Analysis with the help of MINITAB 14, SPSS for Windows version 16.0, Ms Excel and STATISTICA 8.Results of canonical correlation analysis based on respondents generally produced three factors that most influence the purchase of real to buy Magnum ice cream, namely factors friend (0666), knowledge of attributes (0519), trust (0515), and advertising (0.56). The results of the analysis of students based on canonical correlation produced three factors that influence the purchase of real to buy cream of Magnum of ice, i.e., factor of student (0.816), confidence (0.736), and personality (0.725). In students, the most influential factor is the factor of sales people and advertisements.

Key words: Effectiveness of Television Advertising, Consumer Decision Model, Canonical Correlation.
\end{abstract}

\section{Pendahuluan}

Semakin ketatnya persaingan dalam dunia usaha memacu para perusahaan untuk menggunkan media promosi yang beragam dalam menarik perhatian konsumen. Salah satu media promosi yang sering dimanfaatkan perusahaan adalah iklan televisi. 
Persaingan usaha melalui iklan tampak pada berlomba-lombanya suatu perusahaan menyajikan iklan yang menarik, unik, dan beda dari yang lain. Menurut survey A.C.Nielsen tentang belanja iklan didapat bahwa belanja Iklan naik $29 \%$ di semester pertama 2010 dibandingkan dengan 2009, televisi melompat tertinggi dengan 35\% mencapai lebih dari Rp. 17 triliun, koran memiliki pertumbuhan lebih lambat dibandingkan dengan periode yang sama dengan 21\% dengan hampir Rp. 10 triliun, sedangkan Majalah \& Tabloid meningkat 3\% dengan total Rp. 973 Milyar.

Tingkat pertumbuhan pasar es krim di Indonesia meningkat sedikitnya 20 persen setiap tahunnya. Pada tahun 2007 total pasar es krim sudah mendekati angka 100 juta liter dengan nilai absolut diatas Rp. 2 triliun. Adapun perusahaan es krim nasional dapat dihitung dengan jari, yaitu PT Campina Ice Cream Industri yang mengusung merek Campina; PT Unilever Indonesia denga merek Wall's; PT Indomeiji Dairy Food yang mengusung merek Indo es krim Meji; dan PT Sukanda Jaya dengan merek Diamond. Kendati pemainnya sedikit, persaingan es krim tergolong cukup sengit, terutama bagi dua pemain terbesar, yaitu Walls dan Campina yang menguasai hampir $80 \%$ pasar. Wall's sebagai perusahaan es krim dengan pangsa pasar besar di Indonesia juga menggunakan iklan televisi untuk mempromosikan produknya, salah satunya Magnum.

Tabel 1. Total Belanja Iklan Walls pada Semua Media

\begin{tabular}{cc}
\hline Tahun & Total Belanja (Dalam Milyar Rupiah) \\
\hline 2005 & 106 \\
2006 & 120 \\
2007 & 172 \\
\hline
\end{tabular}

Sumber: Nielsen Media Research, 2010

Kembali diluncurkannya iklan Magnum ini terkait dengan peremajaan produk dengan menciptakan image baru dari produk tersebut yang tujuannya untuk menubah sikap dan perilaku konsumen. Hal ini dilakukan karena pada Product Life Cycle (PLC) produk Magnum tengah menghadapi masa penurunan. Untuk mengatasi masa penurunan tersebut, wall's melakukan suatu inovasi pada Magnum, salah satunya dengan melakukan komunikasi pemasaran dengan menayangkan iklan di televisi. Iklan terbaru Magnum ini mengusung Magnum baru yang menggunakan Belgian Chocolate yang terdiri dari tiga rasa yaitu, Classic Magnum, chocolate Truffle Magnum, dan Almond Magnum.

Konsep iklan yang menggunakan seorang wanita sebagai model dengan menonjolkan image Magnum yang mewah dan klasik. Iklan tersebut menggambarkan konsumen yang selalu bergelut dengan waktu dan kesibukan kehidupan modern, momen untuk merasakan pleasure indulgence seperti ini sulit untuk direalisasikan. Kebutuhan memanjakan diri seperti liburan keluar kota, santai di spa, dan sebagainya merupakan kebutuhan pelengkap dan menjadi bagian dari hak pribadi setiap orang. Melihat kebutuhan tersebut, Wall's Magnum berperan untuk membantu para konsumen melepaskan diri dari kehidupan modern yang sangat sibuk untuk bisa merasakan kenikmatan luar biasa, intens, dan sensorial seperti dimanjakan layaknya seorang putri. 
Gender adalah faktor penentu yang dominan mengenai bagaimana seseorang memandang dunia dan segalanya. Perempuan dan pria secara tidak sadar menggunakan peran gender untuk menyaring informasi dalam membuat keputusan apa yang diyakini terhadap pemilihan produk, pesan merek atau lingkungan penjualan. Perempuan dan pria menekankan nilai yang berbeda berdasarkan pengalaman masingmasing. Es krim disukai oleh semua kalangan, baik tua maupun muda, laki-laki atau perempuan. Dengan melihat iklan televisi Magnum yang lebih memperlihatkan segmentasinya adalah perempuan, bukan berarti laki-laki tidak menjadi segmentasinya. Semakin bersaingnya jumlah popusasi antara perempuan dan laki-laki perlu diperhatikan oleh para perusahaan. . Iklan Magnum ini tentu saja menelan biaya yang besar. Untuk itu menarik untuk dikaji seberapa besar efektivitas penayangan iklan Magnum dalam keputusan pembelian berdasarkan gender pada mahasiswa. tujuan dilaksanakannya penelitian ini adalah:

1. Menganalisis efektivitas iklan televisi Magnum dalam mengkomunikasikan pesan iklannya berdasarkan gender kepada mahasiswa Strata-1 Institut Pertanian Bogor.

2. Menganalisis faktor yang mempengaruhi pembelian nyata mahasiswa berdasarkan gender dalam pembelian es krim Wall's Magnum oleh mahasiswa strata-1 Institut Pertanian Bogor.

\section{Metode Penelitian}

Konsumen yang masuk dalam penelitian ini adalah mahasiswa Strata-1 Institut Pertanian Bogor, yang akan dilihat dalam pengambilan keputusan pembelian antara laki-laki dan perempuan. Keputusan pembelian konsumen yang didasarkan pada niat beli terlebih dahulu dipengaruhi oleh lingkungan, perbedaan individu, dan proses psikologis. Penelitian ini menggunakan dua alat analisis, yaitu Consumer Decision Model (CDM) yang digunakan untuk mengetahi efektivitas iklan televise es krim Magnum, dan analisis canonical correlation untuk menganalisis pengaruh iklan dan faktor-faktor yang mempengaruhi niat beli es krim Magnum oleh konsumen laki-laki dan perempuan. Kerangka pemikiran dapat dilihat pada Gambar 1.

Penelitian ini dilakukan di kampus Institut Pertanian Bogor dimana respondennya adalah mahasiswa Strata-1 IPB. Pemilihan lokasi penelitian ditentukan dengan criteriakriteria yang telah ditetapkan (purposive). Waktu yang dibutuhkan untuk melakukan penelitian ini yaitu bulan Februari hingga April 2011.

Data yang digunakan dalam penelitian ini terdiri dari data primer dan data sekunder. Data primer diperoleh dari hasil penyebaran kuisioner kepada responden, yaitu mahasiswa strata-1 IPB. Data sekunder di peroleh melalui studi literature dari berbagai sumber seperti buku, internet, majalah, dan sebagainya. 


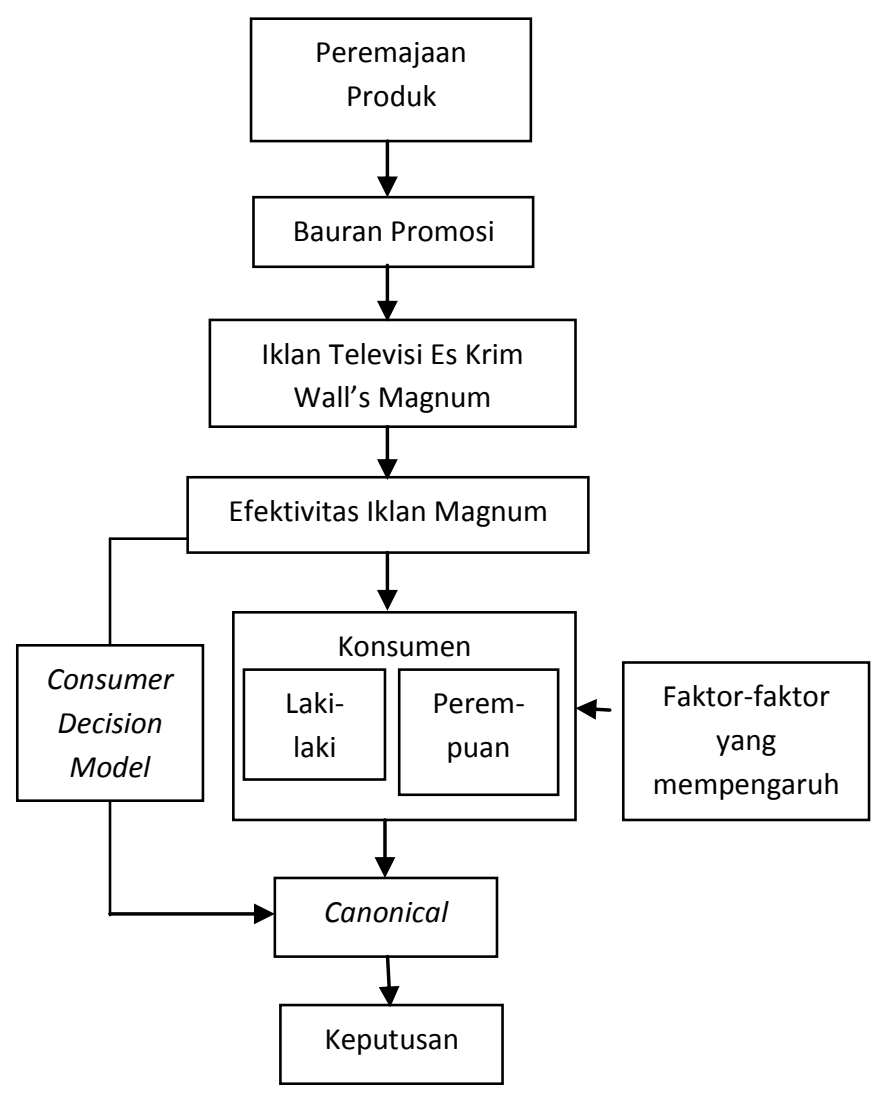

Gambar 1. Kerangka Pemikiran

Sampel adalah bagian dari populasi yang diharapkan dapat mewakili populasi penelitian. Populasi dalam penelitian ini sendiri yaitu mahasiswa Strata-1 Institut Pertanian Bogor yang berjumlah 15574 orang per periode 30 September 2010. Pada penelitian ini digunakan teknik pengambilan sampel dengan nonprobability sampling di mana probabilitas masing-masing anggota populasi tidak diketahui. Teknik nonprobability sampling yang digunakan adalah convenience sampling, yaitu prosedur untuk mendapatkan unit sampel menurut keinginan peneliti (Kuncoro, 2003). Dari rumus Slovin, maka didapat 99,36 dibulatkan menjadi 100 mahasiswa untuk dijadikan responden yang kemudian sample dikuotakan berdasarkan gender yaitu, laki-laki dan perempuan, sebagai berikut:

- Laki - laki $=\frac{6492}{15547} \times 100=41.76 \approx 42$ mahasiswa

- Perempuan $=\frac{9055}{15547} \times 100=58.24 \approx 58$ mahasiswi

Dalam pengujian kuesioner, harus diperhatikan dua hal, yaitu 1) validitas dan 2) reliabilitas. Hal ini dilakukan agar kuesioner yang digunakan benar-benar akurat dan layak untuk disebar kepada responden.

Uji validitas digunakan untuk mengetahui kelayakan butir-butir dalam suatu daftar (konstruk) pertanyaan dalam mendefinisikan suatu variable. Data dikatakan valid apabila nilai korelasi hitung data tersebut melebihi nilai korelasi tabelnya. Jika $r_{\text {hitung }}$ positif dan $r_{\text {hitung }}$ lebih besar daripada nilai $r_{\text {tabel, }}$ maka butir pertanyaan atau variable tersebut dikatakan valid. 
Menurut Kuncoro (2003), reliabilitas menunjukkan konsistensi dan stabilitas dari suatu skor (skala pengukuran). Reliabilitas berbeda dengan validitas karena reliabilitas memusatkan perhatian pada masalah konsistensi, sedangkan validitas memperhatikan masalah ketepatan. Pengujian reliabilitas yang digunakan yaitu teknik Cronbach. Nilai Cronbach's Alpha dapat dihitung dengan bantuan program Excel dan software SPSS Ver.15.0 for windows. Reliabilitas suatu konstruk variabel dikatakan baik jika memiliki nilai Cronbach's Alpha lebih dari 0,60 Nugroho, 2005).

Penelitian ini menggunakan metode analisis kuantitatif dengan menggunakan pendekatan konsep-konsep manajemen pemasaran yang ada.

Model dengan enam peubah yang saling berhubungan, yaitu Pesan Iklan ( $F$, finding information), Pengenalan Merek ( $B$, brand recognition), Kepercayaan Konsumen ( $C$, confidence), Sikap Konsumen (A, attitude), Niat Beli (I, intention) dan Pembelian Nyata $(P$, purchase) dianalisis dengan menggunakan regresi linier baik yang sederhana maupun berganda. Regresi linier digunakan untuk melihat hubungan antar variabel satu dengan lainnya (Gambar 2).

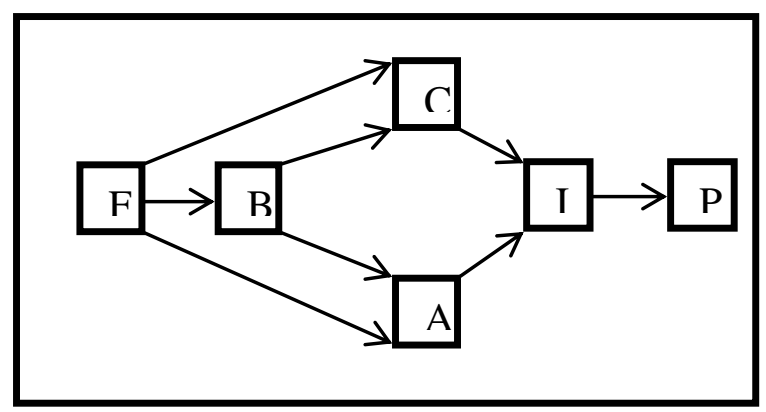

Gambar 2. Consumer Decision Model

Untuk mengetahui efektivitas iklan dengan menggunakan CDM digunakan analisis bentuk hubungan dan analisis keeratan hubungan. Pengaruh langsung variabel independen terhadap variabel dependen ditelusuri dengan analisis regresi. Analisis regresi yang digunakan memperhatikan prinsip parsimony, yaitu semakin sederhana suatu model semakin bagus model tersebut, dan dengan pertimbangan efisiensi dan kemudahan pemahaman model tersebut dari sisi pengguna (Durianto, 2003). Model populasi yang digunakan adalah :

dalam hal ini :

$$
Y_{i}=\alpha+\beta X_{i}+\varepsilon_{i}
$$

$\mathrm{Y}_{\mathrm{i}}=$ Variabel dependent

$\mathrm{X}_{\mathrm{i}}=$ Variabel independent

$\alpha=$ Intercept model

$\beta=$ Parameter regresi

\section{$\varepsilon=$ error term}

Pada persamaan tersebut akan dianalisis persamaan regresi sederhana antara variabel pesan iklan $(F)$ dengan pengenalan merek $(B)$, pesan iklan $(F)$ dengan kepercayaan konsumen (C), pesan iklan ( $F$ ) dengan sikap konsumen (A). Pada ketiga persamaan tersebut, variabel pesan iklan $(F)$ menjadi variabel independen dan variabel B, C, dan A menjadi variabel dependen. Persamaan regresi berikutnya adalah 
persamaan regresi antara variabel pengenalan merek (B) dengan kepercayaan konsumen $(C)$, pengenalan merek $(B)$ dengan sikap konsumen $(A)$, dengan variabel $B$ sebagai variabel independen dan variabel $C$ dan $A$ sebagai variabel dependen. Persamaan berikutnya yang akan dianalisis adalah persamaan regresi sederhana antara variabel niat beli (I) dengan kepercayaan konsumen (C), dan niat beli (I) dengan sikap konsumen (A). Persamaan kedua, variabel I menjadi variabel dependen dan variabel $C$ dan $A$ menjadi variabel independen. Persamaan regresi berikutnya yang akan dianalisis adalah persamaan regresi antara variabel pembelian nyata $(P)$ dengan variabel niat beli (I). Pada persamaan ketiga terakhir, variabel $\mathrm{P}$ menjadi variabel dependen dan variabel I menjadi variabel independen.

Analisis korelasi kanonik merupakan teknik statistika yang digunakan untuk mengidentifikasi dan mengkuantifikasi hubungan diantara dua gugus peubah. Dalam penelitian ini yang menjadi gugus peubah dependen $(Y)$ adalah pembelian nyata konsumen pada minuman isotonik dan yang menjadi gugus peubah independen adalah faktor yang mempengaruhi perilaku konsumen. Analisis ini dilakukan untuk mencari faktor perilaku konsumen apa saja yang mempengaruhi pembelian nyata konsumen pada minuman isotonik yang diamati berdasarkan lima peubah pembelian nyata, yaitu pembelian nyata modern $\left(Y_{1}\right)$, pembelian nyata kesan $\left(Y_{2}\right)$, pembelian nyata karakter $\left(Y_{3}\right)$, pembelian nyata mudah $\left(Y_{4}\right)$, dan pembelian nyata singkat $\left(Y_{5}\right)$. Faktor perilaku konsumen yang digunakan dalam penelitian ini terdiri dari dua puluh satu variabel, yaitu status sosial $\left(X_{1}\right)$, teman $\left(X_{2}\right)$, keluarga $\left(X_{3}\right)$, banyak aktivitas $\left(X_{4}\right)$, wiraniaga $\left(X_{5}\right)$, besar pengeluaran $\left(X_{6}\right)$, jenis aktivitas $\left(X_{7}\right)$, variasi rasa $\left(X_{8}\right)$, bentuk kemasan $\left(X_{9}\right)$, ukuran kemasan $\left(X_{10}\right)$, harga $\left(X_{11}\right)$, merek $\left(X_{12}\right)$, manfaat mengkonsumsi $\left(X_{13}\right)$, pengetahuan atribut $\left(X_{14}\right)$, pengetahuan tempat pembelian $\left(X_{15}\right)$, kepercayaan $\left(X_{16}\right)$, kepribadian $\left(X_{17}\right)$, gaya hidup $\left(X_{18}\right)$, iklan $\left(X_{19}\right)$, media informasi $\left(X_{20}\right)$, dan pengalaman $\left(\mathrm{X}_{21}\right)$.

Prinsip dari metode ini yaitu membentuk suatu kombinasi linier dari setiap gugus peubah (dependen dan independen) sedemikian sehingga korelasi diantara kedua gugus peubah tersebut menjadi maksimum. Nilai korelasi kanonikal didapat dari operasi aritmatika matriks korelasi kedua himpunan variabel (variat kanonikal).

Interpretasi koefisien variat kanonikal, dapat dilihat pada bobot kanonikal (canonical weights) dan beban kanonikal (canonical loadings). Bobot kanonikal merupakan koefisien kanonik yang telah dibakukan, dapat diinterpretasikan sebagai besarnya kontribusi variabel asal terhadap variat kanonikal. Semakin besar nilai koefisien ini menyatakan semakin besar kontribusi variabel yang bersangkutan terhadap variat kanonikal. Muatan kanonikal dapat dihitung dari korelasi antara variabel asal dengan masing-masing variabel kanoniknya. Semakin besar nilai loading atau muatan mencerminkan semakin dekat hubungan fungsi kanonik yang bersangkutan dengan variabel asal.

\section{Hasil Penelitian}

Berdasarkan hasil analisis Consumer Decision Model diketahui bahwa iklan televisi es krim magnum yang telah ditayangkan mampu mengkomunikasikan pesan yang ingin disampaikan oleh produsen Magnum dengan cukup efektif kepada konsumen. Pesan iklan (F) yang ingin disampaikan oleh produsen magnum melalui iklan televisi 
berpengaruh terhadap variabel-variabel yang diukur pada CDM sampai dengan variabel pembelian nyata $(P)$. Baik responden umum, maupun berdasarkan gender mahasiswa, pesan iklan (F) mempunyai pengaruh langsung terhadap variabel pengenalan merek (B), kepercayaan konsumen (C), sikap konsumen (A). Variabel pengenalan merek (B) memiliki pengaruh langsung terhadap variabel kepercayaan konsumen (C) dan variabel sikap konsumen (A). Variabel kepercayaan konsumen (C) memiliki pengaruh langsung terhadap variabel niat beli (I). Variabel sikap konsumen (A) memiliki pengaruh langsung terhadap satu variabel, yaitu variabel niat beli (I). Variabel niat beli (I) hanya memiliki pengaruh langsung terhadap satu variabel, yaitu variabel pembelian nyata $(P)$. Untuk responden secara umum dan mahasiswa berdasarkan gender variabel pesan iklan (F) dan variabel pengenalan merek (B) memiliki pengaruh langsung baik bersama-sama maupun parsial terhadap variabel kepercayaan konsumen $(C)$ dan variabel sikap konsumen $(A)$, namun pada mahasiswa pesan iklan (F) dan pengenalan merek (B) signifikan secara serempak namun tidak parsial terhadap variabel sikap konsumen (A). Pada mahasiswa dan mahasiswi, variabel kepercayaan konsumen (C) dan variabel sikap konsumen (A) memiliki pengaruh langsung secara bersama-sama terhadap variabel niat beli (I), namun tidak berpengaruh secara parsial. Untuk pengaruh tidak langsung, pada mahasiswi variabel pesan iklan (F) memiliki pengaruh tidak langsung terhadap variabel kepercayaan konsumen (C) dan sikap konsumen (A) melalui variabel antara pengenalan merek (B). Pesan iklan ( $F$ ) juga memiliki pengaruh tidak langsung terhadap variabel niat beli (I) melalui variabel sikap konsumen (A) sebagai variabel antara. Terakhir variabel sikap konsumen memiliki pengaruh tidak langsung terhadap pembelian nyata melalui variabel antara yaitu variabel niat beli (I). untuk mahasiswa, pengaruh tidak langsung pesan iklan (F) memiliki pengaruh tidak langsung terhadap niat beli (I) melalui dua variabel antara, yaitu variabel kepercayaan konsumen (C) dan variabel sikap konsumen (A). untuk responden secara umum, terdapat tiga variabel antara, diantaranya pesan iklan (F) memiliki pengaruh tidak langsung terhadap niat beli (I) melalui variabel antara kepercayaan konsumen (C) dan sikap konsumen (A), dan pesan iklan (F) berpengaruh tidak langsung terhadap kepercayaan konsumen (C) melalui variabel antara pengenalan merek (B).

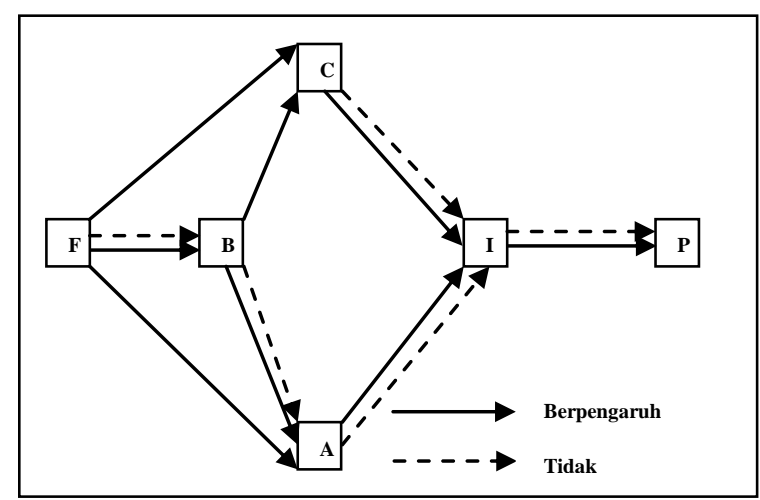

Gambar 3. Hasil Consumer Decision Model Es Krim Wall's Magnum pada Mahasiswa Secara Umum 


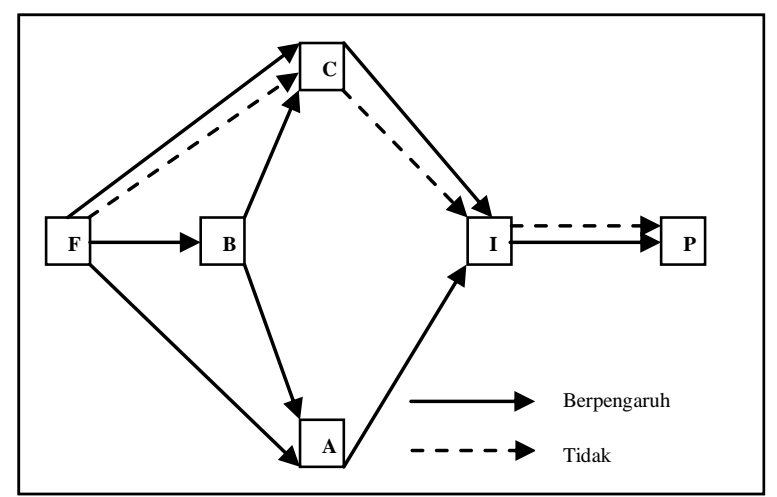

Gambar 4. Hasil Consumer Decision Model Es Krim Wall's Magnum pada Mahasiswi

Hubungan linier antar peubah-peubah dependen $(Y)$, yaitu pembelian nyata konsumen dengan peubah independen $(X)$, yaitu faktor-faktor yang mempengaruhi perilaku konsumen. Pada responden secara umum, nilai korelasi antara pembelian nyata es krim Wall's Magnum dengan faktor yang mempengaruhi perilaku konsumen yang didapatkan menunjukkan nilai kurang dari 0,5 . Hal ini dapat dikatakan bahwa hubungan antara gugus peubah independen $(X)$ dengan gugus peubah dependen $(Y)$ secara umum adalah lemah.

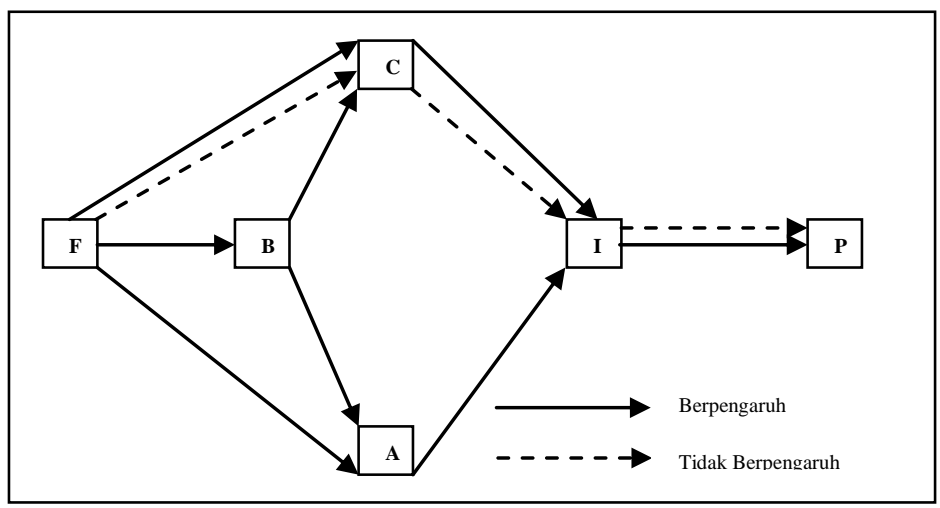

Gambar 5. Hasil Consumer Decision Model Es Krim Wall's Magnum pada Mahasiswa

Serupa dengan responden secara umum, pada mahasiswi nilai korelasi antara pembelian nyata es krim Wall's Magnum oleh mahasiswa perempuan dengan faktor yang mempengaruhi perilaku konsumen yang didapatkan menunjukkan nilai kurang dari 0,5. Hal ini dapat dikatakan bahwa hubungan antara gugus peubah independen (X) dengan gugus peubah dependen $(\mathrm{Y})$ secara umum pada mahasiswi adalah lemah.

Pada mahasiswa nilai korelasi antara pembelian nyata es krim Wall's Magnum dengan faktor yang mempengaruhi perilaku konsumen yang didapatkan menunjukkan nilai lebih dari 0,5 , yaitu sebesar 0,526977 pembelian kesan $\left(Y_{2}\right)$ memiliki hubungan dekat denga faktor iklan $\left(\mathrm{X}_{18}\right)$ dan pembelian mudah $\left(\mathrm{Y}_{4}\right)$ memiliki hubungan dekat dengan faktor iklan $\left(X_{18}\right)$ dengan nilai korelasi sebesar 0,525776. Berarti hubungan antara gugus peubah independen $(X)$ dengan gugus peubah dependen $(Y)$ secara umum pada mahasiswa adalah cukup kuat. Korelasi antar peubah faktor-faktor yang mempengaruhi perilaku konsumen (X). 
Untuk reaponden mahasiswa secara umum, pasangan peubah bebas yang memiliki hubungan kuat pada konsumen es krim Wall's Magnum adalah antara peubah merek $\left(X_{11}\right)$ dan kepercayaan $\left(X_{15}\right)$ dengan nilai korelasi 0,504556. Kedua peubah tersebut saling menguatkan dalam mempengaruhi pembelian konsumen. Hal ini dikarenakan, secara umum konsumen mempercayai suatu produk karena merek tersebut sudah dikenal dan dipercaya banyak orang. Pada mahasiswa perempuan, pasangan peubah bebas yang memiliki hubungan kuat pada konsumen es krim Wall's Magnum adalah antara peubah bentuk kemasan $\left(X_{8}\right)$ dan ukuran kemasan $\left(X_{9}\right)$ dengan nilai korelasi sebesar 0,722. Kedua peubah tersebut memang saling menguatkan dalam pelaksanaannya, karena kedua peubah ini sama-sama mengenai kemasan, dimana keduanya sama-sama dapat dilihat menggunakan indera penglihatan yang dapat mempengaruhi mahasiswa perempuan dalam pembelian nyata es krim Wall's Magnum. Peubah iklan $\left(X_{18}\right)$ memiliki korelasi yang cukup kuat dengan peubah media informasi $\left(X_{19}\right)$ dengan nilai 0,5948 . Kedua peubah tersebut memang saling menguatkan, karena iklan membutuhkan media informasi untuk menyebarluarkan pesan iklan yang ingin disampaikan oleh produsen kepada konsumen es krim Wall's Magnum. Peubah kepribadian $\left(X_{16}\right)$ memiliki korelasi yang cukup kuat dengan gaya hidup $\left(X_{17}\right)$ dengan nilai korelasi sebesar 0,543 . Hal tersebut dapat dijelaskan, karena kepribadian seseorang yang akan menciptakan gaya hidupnya. Kepribadian seseorang yang patuh akan membeli es krim Wall's Magnum sesuai dengan kondisi tubuhnya, hal ini berarti seseorang tersebut memiliki gaya hidup yang sehat dengan patuh menjaga makanan dan tubuhnya. Pada mahasiswa, peubah bentuk kemasan $\left(X_{8}\right)$ dan ukuran kemasan $\left(X_{9}\right)$ dengan nilai korelasi sebesar 0,746 . Kemudian, peubah media informasi ( $\left.X_{19}\right)$ memiliki korelasi cukup kuat dengan peubah iklan $\left(X_{18}\right)$ dan pengalaman terdahulu $\left(X_{20}\right)$ dengan nilai korelasi 0,6616 dan 0,5938. Peubah media informasi $\left(X_{19}\right)$ juga berkorelasi cukup kuat dengan peubah tempat pembelian $\left(X_{14}\right)$ dengan nilai korelasi sebesar 0,561. Iklan membutuhkan media informasi untuk menyebarluarkan pesan iklan yang ingin disampaikan oleh produsen kepada konsumen es krim Wall's Magnum dan dengan adanya media informasi konsumen dapat mngetahui pengalaman terdahulu yang telah dirasakan diri sendiri maupun konsumen lain. Media informasi juga sangat penting dalam memberitahukan mengenai tempat pembelian, dari media informasi tersebut konsumen dapat mengetahui di manakah bisa menemukan es krim Wall's Magnum. Hal ini sesuai dengan hasil korelasi yang cukup kuat yang didapatkan dari kedua peubah tersebut.

Pembelian nyata responden mahasiswa secara umum untuk melakukan pembelian es krim Wall's Magnum yang memiliki pesan iklan yang mudah diingat $\left(\mathrm{Y}_{4}\right)$ memiliki korelasi paling kuat dengan pembelian mahasiswa es krim Wall's magnum yang memiliki pesan iklan yang singkat penayangannya $\left(Y_{5}\right)$, yaitu sebesar 0,720 . Seluruh nilai korelasi antara peubah pembelian nyata mahasiswa secara umum $(\mathrm{Y})$ memiliki nilai di atas 0,1 dengan arah korelasi positif, artinya korelasi antara peubah pembelian nyata mahasiswa secara umum cukup kuat dan searah, meningkatnya nilai salah satu peubah pembelian nyata konsumen berarti bahwa peubah pembelian nyata mahasiswa secara umum lainnya juga meningkat, begitu pula sebaliknya. Pembelian nyata mahasiswi untuk melakukan pembelian es krim Wall's Magnum yang memiliki pesan iklan yang mudah diingat $\left(\mathrm{Y}_{4}\right)$ memiliki korelasi paling kuat dengan pembelian 
mahasiswi es krim Wall's Magnum yang memiliki pesan iklan yang singkat penayangannya $\left(Y_{5}\right)$, yaitu sebesar 0,779 . Pembelian mahasiswi untuk membeli es krim Wall's Magnum yang mencerminkan gaya hidup modern $\left(Y_{1}\right)$ memiliki hubungan yang cukup kuat dengan pembelian karakter mahasiswi $\left(\mathrm{Y}_{3}\right)$ dengan nilai 0,533 . Kemudian pembelian karakter es krim wall's Magnum yang nikmat, berkelas dan mewah memiliki hubungan yang cukup kuat dengan pembelian es krim Wall's Magnum yang menampilkan kesan bahwa konsumen yang mengkonsumsi produk Wall's Magnum akan merasakan kenikmatan dengan cita rasa tinggi, dengan nilai korelasi 0,500. Seluruh nilai korelasi antara peubah pembelian nyata mahasiswi es krim Wall's Magnum (Y) memiliki nilai di atas 0,1 dengan arah korelasi positif, artinya korelasi antara peubah pembelian nyata mahasiswi cukup kuat dan searah, meningkatnya nilai salah satu peubah pembelian nyata konsumen berarti bahwa peubah pembelian nyata mahasiswi lainnya juga meningkat, begitu pula sebaliknya. Pada mahasiswa, pembelian mahasiswa es krim Wall's magnum yang memiliki pesan iklan yang singkat penayangannya $\left(Y_{5}\right)$ memiliki korelasi paling kuat dengan pembelian nyata mahasiswa untuk melakukan pembelian es krim Wall's Magnum yang memiliki pesan iklan yang mudah diingat $\left(\mathrm{Y}_{4}\right)$, yaitu sebesar 0,668. Seluruh nilai korelasi antara peubah pembelian nyata mahasiswa es krim Wall's Magnum $(Y)$ memiliki nilai di atas 0,1 dengan arah korelasi positif, artinya korelasi antara peubah pembelian nyata mahasiswa cukup kuat dan searah, meningkatnya nilai salah satu peubah pembelian nyata konsumen berarti bahwa peubah pembelian nyata mahasiswa lainnya juga meningkat, begitu pula sebaliknya.

Hasil analisis korelasi kanonik yang dilakukan dengan menggunakan bantuan program STATISTICA 8 menghasilkan fungsi kanonik yang memiliki nilai korelasi maksimum dan menghasilkan persamaan sebagai berikut:

a) Umum

$$
\begin{aligned}
& X^{*}=0,236851 X_{1}+0,666329 X_{2}+0,491174 X_{3}+0,334310 X_{4}+0,105194 X_{5}+ \\
& 0,474908 X_{6}+0,310688 X_{7}+0,203455 X_{8}+0,171821 X_{9}+0,369938 X_{10}+0,297395 \\
& X_{11}+0,169651 X_{12}+0,518683 X_{13}+0,384298 X_{14}+0,514542 X_{15}+0,264876 X_{16}+ \\
& 0,139392 X_{17}+0,560065 X_{18}+0,421020 X_{19}+0,163443 X_{20} \\
& Y^{*}=0,273133 Y_{1}+0,953307 Y_{2}+0,289006 Y_{3}+0,164252 Y_{4}+0,272375 Y_{5}
\end{aligned}
$$

b) Perempuan

$X^{*}=-0,815576 X_{1}+0,343110 X_{2}-0,429273 X_{3}-0,007957 X_{4}+0,288755 X_{5}+$ $0,263681 X_{6}-0,489496 X_{7}+0,462855 X_{8}-0,429884 X_{9}+0,398518 X_{10}+0,275919$ $x_{11}-0,615214 X_{12}-0,032555 X_{13}-0,675829 x_{14}+0,735847 X_{15}+0,702513 x_{16}-$ $0,725264 X_{17}-0,308289 X_{18}+0,419100 X_{19}+0,410383 X_{20}$ $Y^{*}=-0,313768 Y_{1}+0,327300 Y_{2}+0,576928 Y_{3}+0,556668 Y_{4}-0,041887 Y_{5}$

c) Laki-laki

$$
\begin{aligned}
& X^{*}=0,582813 X_{1}+0,313073 X_{2}+0,363016 X_{3}+0,357399 X_{4}-0,008280 X_{5}+0,307021 \\
& X_{6}+0,395304 X_{7}+0,249759 X_{8}+0,266747 X_{9}+0,257717 X_{10}+0,509505 X_{11}+ \\
& 0,062868 X_{12}+0,261858 X_{13}+0,228763 X_{14}+0,410744 X_{15}-0,113461 X_{16}+ \\
& 0,124104 X_{17}+0,647449 X_{18}+0,269369 X_{19}+0,192806 X_{20} \\
& Y^{*}=0,551436 Y_{1}+0,646406 Y_{2}+0,071710 Y_{3}+0,582874 Y_{4}+0,508309 Y_{5}
\end{aligned}
$$

Nilai korelasi yang dihasilkan dari persamaan responden mahasiswa secara umum di atas adalah sebesar 0,640. Untuk dapat melihat seberapa besar pembelian nyata $(Y)$ 
dapat dijelaskan oleh faktor-faktor yang mempengaruhi perilaku konsumen (X) digunakan $\mathrm{R}^{2}$. Berdasarkan hasil pengolahan, nilai $\mathrm{R} 2$ yang di dapat adalah sebesar 0,4096 . Artinya adalah variasi gugus peubah pembelian nyata mahasiswa secara umum yang dapat dijelaskan oleh gugus peubah faktor-faktor yang mempengaruhi perilaku konsumen adalah sebesar 40,96 persen, sisanya 59,04 persen dijelaskan oleh faktor diluar model yang digunakan. Nilai korelasi yang dihasilkan dari persamaan di atas adalah sebesar 0,756 . Untuk dapat melihat seberapa besar pembelian nyata $(Y)$ dapat dijelaskan oleh faktor-faktor yang mempengaruhi perilaku konsumen $(X)$ digunakan $\mathrm{R}^{2}$. Berdasarkan hasil pengolahan, nilai R2 yang di dapat adalah sebesar 0,5714. Artinya adalah variasi gugus peubah pembelian nyata mahasiswa perempuan yang dapat dijelaskan oleh gugus peubah faktor-faktor yang mempengaruhi perilaku konsumen adalah sebesar 57,14 persen, sisanya 42,86 persen dijelaskan oleh faktor diluar model yang digunakan. Nilai korelasi yang dihasilkan dari persamaan di atas adalah sebesar 0,914091 . Untuk dapat melihat seberapa besar pembelian nyata $(\mathrm{Y})$ dapat dijelaskan oleh faktor-faktor yang mempengaruhi perilaku konsumen $(X)$ digunakan $R^{2}$. Berdasarkan hasil pengolahan, nilai $\mathrm{R}^{2}$ yang di dapat adalah sebesar 0,835562 . Artinya adalah variasi gugus peubah pembelian nyata mahasiswa laki-laki yang dapat dijelaskan oleh gugus peubah faktor-faktor yang mempengaruhi perilaku konsumen adalah sebesar 83,56 persen, sisanya 16,44 persen dijelaskan oleh faktor diluar model yang digunakan.

Besarnya bobot kanonik untuk masing-masing peubah asal yang membentuk fungsi kanonik. Faktor-faktor perilaku konsumen $(X)$ yang memiliki bobot kanonik cukup besar (diatas 0,5) dianggap mampu menjelaskan keragaman pembelian nyata untuk membeli es krim Wall's Magnum yang terjadi dan sebaliknya. Untuk mahasiswa secara umum, tidak diperoleh bobot kanonik yang lebih dari 0,5. Hal ini berarti, pada mahasiswa secara umum tidak ada faktor yang mempengaruhi keragaman pembelian nyata mahasiswa secara umum, dengan kata lain semua faktor mempengaruhi pembelian nyata. Pada mahasiswi, berdasarkan interpretasi terhadap bobot kanonik diperoleh bahwa faktor yang paling berpengaruh terhadap pembelian nyata konsumen untuk membeli es krim Walls' Magnum adalah peubah status mahasiswa $\left(X_{1}\right)$ yang memiliki bobot sebesar -0,815576. Hal ini dapat dijelaskan karena dikemunculan kembali es krim Wall's Magnum, sangat menggemparkan masyarakat khususnya mahasiswa. Banyaknya konsumen yang mengupdate status di social media yang mereka miliki membuat banyak mahasiswa semakin penasaran dengan es krim Wall's Magnum. Oleh karena itu, status mahasiswa yang identik dengan manusia yang berfikiran maju dan mengikuti perkembangan zaman, dirasakan perlu sebagai seorang mahasiswa untuk mencoba mengkonsumsi es krim Wall's Magnum. Maka dari itu banyak dari responden yang baru satu kali mengkonsumsi es krim Wall's Magnum, hanya untuk sekedar pernah merasakan es krim Wall's Magnum. Faktor manfaat mengkonsumsi $\left(X_{12}\right)$, pengetahuan tempat pembelian $\left(X_{14}\right)$, kepercayaan $\left(X_{15}\right)$, kepribadian $\left(X_{16}\right)$, dan gaya hidup $\left(X_{17}\right)$ turut memberi pengaruh dalam menjelaskan keragaman pembelian nyata mahasiswi.

Pada mahasiswa, faktor wiraniaga $\left(X_{5}\right)$, besar pengeluaran $\left(X_{6}\right)$, gaya hidup $\left(X_{17}\right)$, dan iklan $\left(X_{18}\right)$ merupakan faktor yang mempengaruhi keragaman pembelian nyata mahasiswa. Peubah iklan merupakan peubah yang memiliki bobot kanonik yang 
tersesar, bahkan sampai lebih dari satu, yaitu sebesar 1,015338. Artinya, peubah iklan merupakan faktor yang paling berpengaruh terhadap keragaman pembelian nyata es krim Wall's Magnum oleh mahasiswa. Faktor wiraniaga juga berpengaruh terhadap keragaman pembelian nyata mahasiswa untuk membeli es krim Wall's Magnum. Tidak sedikit dari mahasiswa laki-laki yang bari melakukan pembelian nyata untuk membeli es krim Wall's Magnum ketika sudah ada di supermarket. Wiraniaga yang berada di supermarket tersebut dapat mempengaruhi konsumen dalam menentukan merek yang akan mereka pilih untuk dikonsumsi, karena wiraniagag dapat memberikan informasi mengenai produk es krim apa saja yang ada di supermarket tersebut beserta keunggulan. Hal ini berpengaruh terhadap informasi yang dimiliki oleh konsumen, konsumen yang mulanya tidak mengetahui merek es krim Wall's Magnum menjadi mengetahui adanya merek es krim tersebut dan memutuskan untuk mencoba mengkonsumsi es krim yang ditawarkan. Berpengaruhnya wiraniaga pada mahasiswa laki-laki, terkait dengan kesukaan laki-laki apabila dihampiri oleh wiraniaga perempuan, yang membuat konsumen tersebut tertarik untuk mengkonsumsi produk tersebut.

Tabel 5. Bobot dan Beban Kanonik

\begin{tabular}{|c|c|c|c|c|c|c|c|}
\hline \multirow{2}{*}{\multicolumn{2}{|c|}{$\begin{array}{c}\text { Variabel } \\
\text { Responden }\end{array}$}} & \multicolumn{3}{|c|}{ Bobot Kanonik } & \multicolumn{3}{|c|}{ Beban Kanonik } \\
\hline & & Umum & Perempuan & Laki-laki & Umum & Perempuan & Laki-laki \\
\hline \multirow[t]{21}{*}{ A. } & Peubah B & & & & & & \\
\hline & $X_{1}$ & $-0,044767$ & $-0,815576$ & 0,230501 & 0,236851 & $-0,363384$ & 0,582813 \\
\hline & $x_{2}$ & 0,352025 & 0,343110 & $-0,251436$ & 0,666329 & 0,131428 & 0,313073 \\
\hline & $x_{3}$ & 0,294497 & $-0,429273$ & 0,446425 & 0,491174 & 0,202972 & 0,363016 \\
\hline & $x_{4}$ & 0,274367 & $-0,007957$ & 0,171652 & 0,334310 & $-0,061484$ & 0,357399 \\
\hline & $X_{5}$ & $-0,330450$ & 0,288755 & $-0,593916$ & 0,105194 & 0,082444 & $-0,008280$ \\
\hline & $x_{6}$ & 0,260074 & 0,263681 & $-0,544860$ & 0,474908 & 0,113310 & 0,307021 \\
\hline & $x_{7}$ & 0,096985 & $-0,489496$ & 0,037890 & 0,310688 & $-0,045710$ & 0,395304 \\
\hline & $x_{8}$ & 0,072541 & 0,462855 & 0,129917 & 0,203455 & 0,177829 & 0,249759 \\
\hline & $X_{9}$ & $-0,266564$ & $-0,429884$ & $-0,113065$ & 0,171821 & $-0,024987$ & 0,266747 \\
\hline & $X_{10}$ & 0,164294 & 0,398518 & 0,310281 & 0,369938 & $-0,013356$ & 0,257717 \\
\hline & $x_{11}$ & $-0,219229$ & 0,275919 & 0,208293 & 0,297395 & 0,198161 & 0,509505 \\
\hline & $x_{12}$ & $-0,089011$ & $-0,615214$ & 0,170546 & 0,169651 & $-0,150636$ & 0,062868 \\
\hline & $\mathrm{X}_{13}$ & 0,173098 & $-0,032555$ & 0,026992 & 0,518683 & 0,274566 & 0,261858 \\
\hline & $X_{14}$ & $-0,260810$ & $-0,675829$ & 0,148058 & 0,384298 & 0,220673 & 0,228763 \\
\hline & $X_{15}$ & 0,453969 & 0,735847 & 0,223543 & 0,514542 & 0,408201 & 0,410744 \\
\hline & $\mathrm{X}_{16}$ & 0,201689 & 0,702513 & $-0,003272$ & 0,264876 & 0,359635 & $-0,113461$ \\
\hline & $X_{17}$ & $-0,148107$ & $-0,725264$ & $-0,555457$ & 0,139392 & 0,100933 & 0,124104 \\
\hline & $\mathrm{X}_{18}$ & 0,414395 & $-0,308289$ & 1,015338 & 0,560065 & 0,135602 & 0,647449 \\
\hline & $X_{19}$ & 0,047345 & 0,419100 & $-0,188342$ & 0,421020 & 0,101060 & 0,269369 \\
\hline & $x_{20}$ & $-0,223890$ & 0,410383 & $-0,008209$ & 0,163443 & 0,272310 & 0,192806 \\
\hline \multirow[t]{6}{*}{ B. } & Peubah T & Bebas & & & & & \\
\hline & $Y_{1}$ & 0,024708 & $-0,313768$ & 0,513367 & 0,273133 & 0,248591 & 0,551436 \\
\hline & $Y_{2}$ & 1,037057 & 0,327300 & 0,691550 & 0,953307 & 0,663963 & 0,646406 \\
\hline & $Y_{3}$ & $-0,174825$ & 0,576928 & $-0,471580$ & 0,289006 & 0,782292 & 0,071710 \\
\hline & $Y_{4}$ & $-0,273349$ & 0,556668 & 0,503234 & 0,164252 & 0,771617 & 0,582874 \\
\hline & $Y_{5}$ & 0,367293 & $-0,041887$ & 0,020428 & 0,272375 & 0,481695 & 0,508309 \\
\hline
\end{tabular}

Sumber: Data primer, 2011

Penelusuran lebih lanjut pada beban kanonik menunjukkan bahwa faktor perilaku konsumen yang paling berpengaruh terhadap pembelian nyata konsumen untuk membeli es krim Wall's Magnum. Untuk mahasiswa secara umum, faktor yang paling 
berpengaruh adalah faktor teman $\left(X_{2}\right)$ dengan nilai loading terbesar $(0,666329)$. Faktor pengetahuan atribut $\left(X_{13}\right)$, kepercayaan $\left(X_{15}\right)$, dan iklan $\left(X_{18}\right)$ turut menjadi faktor yang berpengaruh terhadap pembelian nyata mahasiswa secara umum.

Pada mahasiswi, tidak diperoleh nilai loading yang lebih dari 0,5 , artinya tidak ada faktor yang paling mempengaruhi, melainkan semua faktor pada variabel bebas mempengaruhi terhadap pembelian nyata mahasiswi. Pada mahasiswa, diperoleh nilai loading terbesar pada faktor iklan $\left(\mathrm{X}_{18}\right)$ yang memiliki loading sebesar 0,647449 . Hal ini dapat dijelaskan karena melalui iklan konsumen mengetahui informasi mengenai es krim Wall's Magnum. Sebagai produsen Wall's menggunakan iklan untuk memberitahukan hal-hal yang harus diketahui konsumen, seperti pengetahuan atribut produk, misalnya varian rasa, komposisi, bentuk kemasan, ukuran kemasan, warna kemasan. Dari hal tersebut, konsumen dapat memilah apakah es krim Wall's Magnum dapat memenuhi kebutuhan dan keinginan yang diperlukan atau tidak. Faktor status mahasiswa $\left(X_{1}\right)$ dan merek $\left(X_{11}\right)$ turut memberi pengaruh terhadap pembelian nyata mahasiswa.

Ketatnya persaingan di pasar es krim kemasan sekarang ini, mendorong produsen es krim untuk melakukan berbagai cara untuk menjadi nomor satu. Untuk meningkatkan pangsa pasar maka perusahaan harus menentukan strategi yang tepat untuk mempertahankan loyalitas konsumen yang ada dan juga untuk dapat menarik konsumen baru. Gender konsumen juga tidak bias dilupakan, produsen perlu menetapkan strategi-strategi pemasaran yang tepat untuk masing-masing gender. Untuk mempertahankan eksistensi Wall's Magnum maka diperlukan suatu usaha yang dapat mempertahankan konsumen es krim Wall's Magnum baik perempuan maupun laki-laki, selain itu juga menarik mahasiswa perempuan maupun laki-laki yang sebelumnya belum pernah mengkonsumsi es krim Wall's Magnum untuk mencoba mengkonsumsinya.

\section{Kesimpulan}

Terdapat perbedaan antara mahasiswa laki-laki dengan mahasiswa perempuan dalam proses pengambilan keputusan pembelian es krim Wall's Magnum dan menilai efektivitas iklan es krim Wall's Magnum. Berdasarkan hasil analisis Consumer Decision Model diketahui bahwa iklan televisi es krim Wall's Magnum yang telah ditayangkan mampu mengkomunikasikan pesan yang ingin disampaikan oleh produsen Magnum dengan cukup efektif kepada konsumen. Pesan iklan yang ingin disampaikan oleh produsen magnum melalui iklan televisi berpengaruh terhadap variabel-variabel yang diukur pada CDM sampai dengan variabel pembelian nyata. Baik responden umum, maupun berdasarkan gender mahasiswa, pesan iklan (F) mempunyai pengaruh langsung terhadap variabel pengenalan merek (B), kepercayaan konsumen (C), sikap konsumen (A). Variabel pengenalan merek (B) memiliki pengaruh langsung terhadap variabel kepercayaan konsumen (C) dan variabel sikap konsumen (A). Variabel kepercayaan konsumen (C) memiliki pengaruh langsung terhadap variabel niat beli (I). Variabel sikap konsumen (A) memiliki pengaruh langsung terhadap satu variabel, yaitu variabel niat beli (I). Variabel niat beli (I) hanya memiliki pengaruh langsung terhadap satu variabel, yaitu variabel pembelian nyata (P). Variabel pesan iklan (F) dan variabel pengenalan merek (B) memiliki pengaruh langsung baik bersama-sama maupun parsial 
terhadap variabel kepercayaan konsumen (C) dan variabel sikap konsumen (A), namun pada mahasiswa pesan iklan (F) dan pengenalan merek (B) signifikan secara serempak namun tudak parsial terhadap variabel sikap konsumen (A). Pada mahasiswa dan mahasiswi, variabel kepercayaan konsumen (C) dan variabel sikap konsumen (A) memiliki pengaruh langsung secara bersama-sama terhadap variabel niat beli (I), namun tidak berpengaruh secara parsial. Untuk pengaruh tidak langsung, pada mahasiswi variabel pesan iklan (F) memiliki pengaruh tidak langsung terhadap variabel kepercayaan konsumen (C) dan sikap konsumen (A) melalui variabel antara pengenalan merek (B). Pesan iklan (F) juga memiliki pengaruh tidak langsung terhadap variabel niat beli (I) melalui variabel sikap konsumen (A) sebagai variabel antara. Terakhir variabel sikap konsumen memiliki pengaruh tidak langsung terhadap pembelian nyata melalui variabel antara yaitu variabel niat beli (I). untuk mahasiswa, pengaruh tidak langsung pesan iklan (F) memiliki pengaruh tidak langsung terhadap niat beli (I) melalui dua variabel antara, yaitu variabel kepercayaan konsumen (C) dan variabel sikap konsumen (A). Berdasarkan pada analisis bobot kanonik dan beban kanonik pada analisis korelasi kanonik diperoleh faktor yang paling berpengaruh terhadap pembelian nyata es krim Wall's Magnum untuk mahasiswa secara umum adalah faktor teman, pengetahuan atribut, kepercayaan, dan iklan. Pada mahasiswi adalah faktor status mahasiswa, manfaat mengkonsumsi, pengetahuan tempat pembelian, kepercayaan, kepribadian, dan gaya hidup. Sedangkan, faktor yang mempengaruhi pembelian nyata es krim Wall's Magnum pada mahasiswa adalah faktor wiraniaga, besar pengeluaran, gaya hidup, dan iklan.

\section{DAFTAR PUSTAKA}

Durianto, dkk. 2003. Invasi Pasar dengan Iklan yang Efektif: Strategi, Program, dan Teknik Pengukuran. Gramedia Pustaka Utama, Jakarta. 